\title{
TRANSMODERNITATEA LIMBAJULUI POETIC AL AUREI CHRISTI
}

\author{
Florian COPCEA \\ Drobeta Turnu Severin
}

ORCID: https://orcid.org/0000-0002-4914-377X

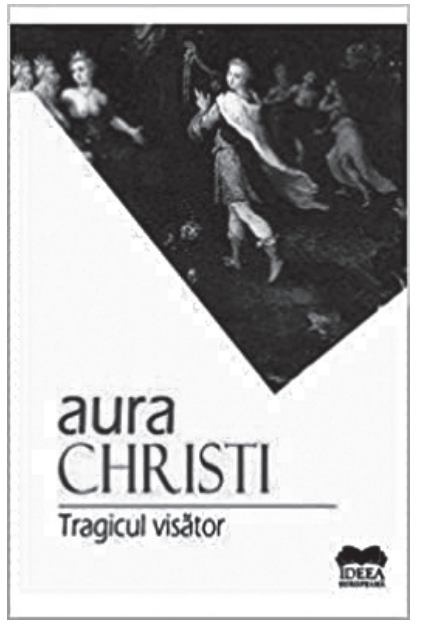

Versurile Aurei Christi din Tragicul visător (Editura Ideea Europeană, 2013), eliberate în interiorul frazării de stereotipul mimesisului arhetipal al generației sale, sunt rezultatul categoric, subtil, al jocurilor de contraste sintactice, excelent întreținute de explorările abisale, metafizice, ale unei retorici inex-pugnabile, de ordin intertextualist: „Cine din mine/ dușmănos îmi poruncește să fiu, să cutremur/ râsul trecerii, cerul neverosimil. Cine/ m-azvârle-n apocalipsă? E bine. Și tremur./ De mine m-ascund în versuri. E-nceput de moarte?/ Noapte. Învăț să respir. Reintru-n viață, poate" (Sonată în palimpsest), și: „Scriu? Învăț să-mi locuiesc mormântul/ și în acest poem: mai adevărat decât mâinile-mi crude,/ mai adevărat decât cutremurul interior” (Elegia marelui intrus, a doua); sau: „Un alt înger dă buzna în viaţa mea,/ mă anunță că-i un mare poet, știe totul;/ prin urmare, stă-n drepturile lui să mă învețe/ cum să mă joc. «Cum scrii tu - nu se mai scrie»,/ îmi strigă în față îngerul-poet. Iar eu/ mai văd viața ca pe un joc de-a poezia,/ ca pe un joc cu mărgele cutremurat, de sticlă./ Tac și mă joc de-a «să fiu eu însămi când nu mai pot fi»" (Tratat despre ingeri). Poezicerile despre producerea actului de creație „în luminișurile interioare” (Închide ochii și pleacă) ale ființei justifică deseori, la Aura Christi, in-formalul trăirilor existențiale în care „eu... este altul” (Rimbaud), de parcă cel din urmă nu-și cunoaște geneza: „În aerul nopții limpede, substanţial,/ voi sta ca pe vremi lângă zidul meu cenușiu,/ numărând, așteptând să treacă timpul - vasal/ secret al eului, reintors în pustiu/ Mă voi gândi să-mi schimb planeta, prietenii,/ să schimb regulile jocului superior/ «de-a poezia», în care te constrângi să fii,/ să te reculegi din infernul interi- 
or..." (Zid cenușiu). Universul poetei, halucinant, fantezist și întruchipat în meditații ontice, este dominat de un ex-centrism senzorial, cu aură livrescă: „Ce gând, ce faptă vrea să împlinească Domnu-n mine,/ în fondul intim al ființei, spre care ceas de ceas mă-ndrept?/ Trecând din eu în eu, mă-ntorc spre mine însămi./ Stau în sicriul luminat, mă văd, respir și mă aștept” (Sonata înveșnicirii) și „Care mi-e drumul? Tiparul meu unde/ Mi l-am uitat? Vine demonul meu prea/ Puternic. Îmi strigă-n față: «Treci puntea!»/ Puntea sunt chiar eu" (A șasea elegie).

Aflate sub semnul transmodernismului, poemele, când atinse de aripa muzei lui Eminescu, când influențate de irizări enigmatice nichitiene, capătă forme extricabile de seducție epică. Depărtat de modelele avangardiste ale postmodernismului, logosul poetei, topit în „granulația textului” (J. Ricardou), nu se vrea o fatalitate, ci un un fapt literar original care anulează vidul dintre idee și formă. Datorită acestei situări paradigmatice ființa poetei se metamorfozează instinctiv într-un vulcan care nu numai că erupe în câmpul inventiv, flexibil, al revelației, dar și produce mutații spațio-temporale în compre-hensiunea ideatică a absolutului: „Eu am trimis de milioane de ori solii veșniciei mele/ în lume. Și din mâini, și din ochi, și din dor am născut,/ îngenunchind așteptarea tuturor așteptărilor... Dar până la/ timpul meu ce va da rodului - imperialul rod,/ drumul este încurajator de lung!” (Lumea mea nouă); sau: „Eram călcâiul unui mit/ neștiut, care-și amâna cu voluptate venirea/ printre cărturarii subteranei învinse, ontice,/ Un vesel necunoscut îmi declara că împreună/ cu patru-cinci inși, de pe teritoriile pontice/ ale poeziei, stăpânesc lumea, asupra-i cunună/ o sprijin, o fixez în dosare-nvinse, orgolios completate cu păsări, scoici, plante, sisteme din parfum/ de imortele, din resturile poeziei, pe os/ de voievod încolăcite ca șuvițele de fum..." (Autoimitaţie). Mitul artei scrisului este recuperat imagistic, ipostazele ascensionale ale lumii întruchipate de acesta și văzută în oglinzile alterității, declină, justițiar, miracolul activat între viață și literatură. Identitatea auctorială, încifrat transcrisă în misterii deloc aleatorii, se supune, incan-tatoriu, „,incitând rigoarea/ celui din urmă frig”, „în lăcașul eului” împins în ficțiunea propriului text: „E frig și nu mai vine noaptea/ [...]/ Pun piatră lângă piatră, verb lângă verb./ Lumina-i tot mai aspră către seară./ Iar versu-i ca o foaie de șmirghel,/ ca icnetul în coama Niagarei.// Ferestrele cresc înspre cer. E frig” (Nu mai vine noaptea), și: „Poezia devenise realitatea mea de oțel./ Mă simțeam uneori acasă între silabele ei,/ din care mă ridicam asemeni unui extatic miel/ din grămezile de cenușă din spatele casei.// Mă ascundeam în realitatea aceea. Aș fi vrut/ să- 
mi înghețe sufletul acolo și utopiile,/ și trupul să mi-l uit pe totdeauna acolo" (Hotar de silabe).

Volumul Tragicul visător este, așadar, o combinație dezambiguizată dintre „realitatea vicleană” (aceasta certificând existența în timp și spațiu a poetei) și ficțiune (cea din urmă fiind, cum aserționa Raymond Ferderman, „un mod de a aboli realitatea"), revelând astfel, datorită flexionarului proces de semnificare, capacitatea cognitivă de a defini exact temeiurile creației. În consecință, Aura Christi se dovedește a fi stăpânită perpetuu, în travaliul căutării esenței poeziei, de o stare de iminență proteică, sacră: „Eu voi urmări aceeași Voce, târziu./ Prin noapte voi înainta ca prin mine,/ ca pe limita incan-descentă, vie,/ ce nu mi-a aparținut, nu-mi aparține.../ Sunt aceeași femeie absolută. Știu:/ sunt doar mâna prin care Vocea se scrie” (Vocea) și: „Când se termină visele, scriu,/ să mă trezesc din visul care sunt./ Și iarăși e toamnă. Și iarăși/ cerul sfârșește-n fluturi. Parcă dorm/ și visez, scriind același poem demult./ [...]/ Cuvintele cad precum niște speriați lilieci./ În magma, unde stă ghemuit poemul,/ mă voi trezi din agonia fricii, solară" (Când se termină visele); sau: „Să ne imaginăm că totul nu e decât un joc./ Da, nimic mai mult decât un joc sau un mit/ găsit într-o carte uitată, cu coperțile ude/ - scrisă de o ierarhie de lari depășiți -/ din care nimeni nu mai pricepe nimic/ și nici nu vede felul în care Omphalos/ ne-arată câtă eternitate în noi se ascunde" (Omphalos).

Privită din perspectiva logicii aristotelice, poezia Aurei Christi trădează un eu avid de sensuri parasimpatice și labirintice în care, sinestezic, își află ființa adevărul și irealul unei lumi posibile, cu o rânduială bizară, demonstrând raţionamente poetice realizate prin tehnici de expresie transmoderne, greu de egalat de altcineva: „El primul a greșit./ El și-a sculptat etericul trup/ într-un singur gând/ supărător de exact/ și cvasinecunoscut/ și a vrut să creadă/ până în pânzele negre,/ până în pânzele albe/ că lumea nouă a început/ [...]/ el singur participa/ la tristul spectacol/ al lumii vechi care nu l-a adăpostit" (Tragicul visător); sau: „Zeii nu au dreptul să fugă./ Zeii nu au dreptul să mintă./ Sau poate ei sunt în dreptul/ de a minți atât de covârșitor,/ încât și material, și gândul/ își continuă existența,/ la nesfârșit renăscându-i./ [...]/ Cu o sfâșietoare candoare,/ alerg, alerg, alerg în febra terestră/ către orizonturile desăvârșirii/ în care tot timpul te naști, renăscându-mă./ Ce nesfârșit poți fi, zeul meu! Ce mare!" (Drepturile zeilor). Limbajul, aparent necodificat, devine un imperios mijloc de exprimare (și nu scop) ceea ce justifică monologul contrastiv de factură intelectual-paradoxală. Prin cultivarea metaforei Aura Christi își asumă liber inefabilul fanteziei și înnobilează discursul cu accesorii semantice 
în extensiune. Distincția gând - idee - cuvânt subliniază în poezia sa adicții recognoscibile, de ordin existențial. Mitul, ușor de detectat în alcătuirile și aporiile vieții, se axează, „într-o subtilă rezonanță eufonică”, cum a sesizat Nicolae Breban, pe „acea ipostaziere/ de eter a poemului” (A cincea elegie), fapt care ne determină să accentuăm că Aura Christi își revendică propria sa hermeneutică. Operarea cu un infrareal producător de ficțiune o proiectează pe traiectoria magnetică a parabolei, țel dorit, la urma urmei, de orice creator în demersul său demiurgic de a re-crea, epic, fantasticul „semn al minții”, cum definea poezia Ion Barbu. Este legitimă ideea că Aura Christi este solul abil venit din margine de anarhie ontologică și necuvânt, fără armura prejudecăților, care anunță revenirea ultramodernismului în poetica românească, omologând și postulând în felul acesta o aproximare a ceea ce am putea numi iluminare. $\mathrm{Nu}$ respingem nici teza că am putea să fim, totuși, martori ai apartenenței sale la heteroglosie, lucru care ne-ar obliga să-i acceptăm non-eul pentru care intenționalitatea (pre)facerii poemului, despre care teriotiza premonitoriu P. Valéry, a însemnat tendința de evaziune în lexic, generatoare de efecte simbolice în universul paradisiac, excelent ilustrate în această ars poetica: „Și când am văzut că nu e nimic de făcut,/ începusem să născocim boli secrete/ în vidul ce era până la urmă plăcut -/ ne ținea de urât în lumile lui discrete./ Vorbeam cu prietenii despre posesie./ Stăpâneam vidul și lumea dintotdeauna,/ desenând hărți utopice pe gresie, în caiete școlărești, unde-nchideam luna,/ cerul, profețiile din bucătărie./ Închideam în sisteme târzii strania/ posesie a lumii prin cuvinte - utopie,/ realitatea ninsă. Și-o botezam Urania./ Și iar vedeam disperați: nu e nimic de făcut/ în vidul ce devenea din ce în ce mai plăcut” (Urania). Aura Christi, asemenea lui Nichita Stănescu, reintroduce „conceptele în poezie” (E. Simion), motivând clar particularitățile definitorii ale modului ei de a se situa chiar și „deasupra metaforei” derivată din limbaj. Deschiderea progresiv-consubstanțială, cosmogonică, spre o scriitură unicat, cu mecanisme ontologice în stare de inflație, „înzidind” sinele, vizează o anumită dedublare a ființei poetice aspirând spre de-tabuizarea lâncezelii lexicale tradiționale. Circumstanțele în care ni se înfățișează Aura Christi în Tragicul visător sunt atât de înșelătoare încât, de la un poem la altul, ai senzația că „stârvul propriului eu” ( $L a$ cules) se scufundă în nisipurile mișcătoare ale dezordinii provocate de un "mare cuvânt uitat" (Peisaj în Duminica Orbilor): „Și mă scufund. Mă scufund/ ca-n sfântul abis neștiut,/ înfruptându-mă din marele nimeni/ în mine-azvârlit din alt trup” (Marele nimeni); sau: „Vorbind cu trupul aștept versul care să-i taie/ respirația. Să taie în carnea lui vie./ Pen- 
tru asta, da, merită să-mi fac viața praf și pulbere./ Aștept, așadar, versul care să scuture la rădăcină/ arborele trupului. Să-l cutremure" (Dintotdeauna). E adevărat, cuvântul „reprezintă gândirea” (M. Foucault) și provoacă intruziunea poetei obsedată de „travaliul creației” (Proust), fapt care argumentează supoziţia lui T.S. Eliot: „Poezia nu este frâul liber lăsat emoției, ci e un mod de a evada de sub imperiul ei”. Sentimentul ascuțit al „sfericului gol”, „vasal al ființei” (Frig), fac obiectul/subiectul poeticii sale prin a cărei „arhitectură” o umbră dedalică „trece din eu spre Eu” (Sonată cu vulturi). Prezența poetei în text, pe cât de tăinuită, pe atât de vizibilă, este reflexul apoteozei, dacă vreți, în spiritul lui R. Barthes: „iată cuvintele mele: sunt limbaj”. Altfel spus, în regimul (de)construcției imaginarului întâlnit în interiorul fiecărui poem se interpun, respingându-se sau atrăgându-se, timpul planificării scriiturii (care reclamă activarea „punerii în abis”), și timpul eminamente poetic (aflat sub incidența comprehensibilităţii scriiturii propriu-zise). Operaţia pe cordul textului favorizează și ilustrează totodată dematerializarea materiei verbale, sacre, și, desigur, încifrarea mesajului în arabescurile misterioase ale transmodernismului: „Zidul creștea văzând cu ochii./ În fața lui el continua să stea./ Gândul la un limbaj ce-ar conține și ar exprima/ totul - încă viu îl mai ținea/ Ca printr-o neagră minune/ zidul spre el se muta./ Trebuia să fugă iute./ Aerul avea fața descompusă de frică./ Vântul sculpta sunete, schelete albind vidul,/ închise-n ele însele, suferinde minute/ [...]/ Un limbaj ce se înfruptă din tine ca dintr-un imperiu/ închis în vecii vecilor într-un eres./ Ai încă ceva de iubit, de văzut, de murit./ Iar și iar nepregătit: stai în fața/ aceluiași zid” (Elegia limitelor). 